\title{
Prawne uwarunkowania nauczania przedsiębiorczości w polskim systemie oświaty
}

\section{Legal conditions of teaching entrepreneurship in Polish educational system}

Streszczenie: Jako przedmiot badawczy artykułu przyjęto regulacje prawne, które stanowią podstawę do wprowadzenia nauczania przedsiębiorczości oraz regulują problematykę zajęć z tego zakresu. Zastosowaną metodą badawczą jest analiza wybranych przepisów prawa. Postawiono hipotezę, że wskazanie podstawy do nauczania przedsiębiorczości w ustawie nie daje wystarczającej gwarancji prowadzenia takich zajęć w przyszłości. Dlatego sformułowano postulat mówiący o konieczności wprowadzenia odpowiedniego przepisu do polskiej Konstytucji. W artykule zaznaczono również, że obecna, trudna sytuacja ekonomiczna powoduje u przedsiębiorców kłopoty finansowe. Mając to uwadze, wskazano zagadnienia dotyczące ryzyka finansowego, które powinny być zaakcentowane w trakcie zajęć z uczniami w ramach podstawy programowej określonej w Rozporzadzeniu Ministra Edukacji Narodowej z dnia 30 stycznia 2018 r. w sprawie podstawy programowej kształcenia ogólnego dla liceum ogólnokształcacego, technikum oraz branżowej szkoły II stopnia (Dz.U. z 2018 r., poz. 467, z późn. zm.). Jako hipotezę przyjęto, że obowiązująca podstawa programowa nie w pełni koresponduje z potrzebami związanymi z nauczaniem o ryzyku wykonywania działalności biznesowej. $Z$ tego powodu zarekomendowano, żeby podstawa programowa zawierała dodatkowo wybrane zagadnienia wynikające z Ustawy z dnia 28 lutego 2003 r. Prawo upadłościowe (tekst jednolity: Dz.U. z 2020 r., poz. 1228, z późn. zm).

\begin{abstract}
The subject of the article are legal regulations that are the grounds for teaching entrepreneurship and which regulate the problems of lessons on this topic. The applied research method is the analysis of selected legal regulations. The hypothesis states that indicating the grounds for teaching entrepreneurship in an act of law does not guarantee the conducting of such lessons in the future. This is why, a postulate has been formulated that there is a necessity to introduce a proper provision to the Polish Constiution. The article also pointed out that present tough economic situation causes financial problems for entrepreneurs. Taking this into consideration, there have been indicated issues concerning financial risk, which should be stressed during lessons with pupils within the base curriculum enclosed in the Decree of the Minister of National Education of 30th January 2018 regarding the base curriculum of general education for secondary school, technical school and specialist school of II degree (Journal of Laws of 2018 item 467 with later amendments). A hypothesis was adopted that the binding base curric-
\end{abstract}


ulum does not fully correspond with the needs of teaching about risk of conducting business activity. Therefore, the recommendation has been made that the base curriculum should additionally contain selected regulations resulting from the Statute of 28 February 2003 Bankruptcy Law (consolidated text: Journal of Laws of 2020 item 1228 with later amendments).

Słowa kluczowe: nauczanie; oświata; prawo; przedsiębiorczość

Keywords: education; entrepreneurship; law, teaching

Otrzymano: 17 lutego 2021

Received: 17 February 2021

Zaakceptowano: 20 maja 2021

Accepted: 20 May 2021

\section{Sugerowana cytacja/Suggested citation:}

Woroniecki, P.M. (2021). Prawne uwarunkowania nauczania przedsiębiorczości w polskim systemie oświaty. Przedsiębiorczość - Edukacja [Entrepreneurship - Education], 17(1), 90-103. https:// doi.org/10.24917/20833296.171.7

\section{Normatywne ramy rozważań i cele opracowania}

Edukacja z zakresu przedsiębiorczości uwarunkowana jest treścią przepisów prawa (zob. niżej) i to w dwojakim znaczeniu. Po pierwsze, regulacje prawne stanowią ogólną normatywną podstawę do wprowadzenia odpowiednich zajęć w szkołach. Po drugie, prawne uwarunkowania nauczania przedsiębiorczości można rozumieć jako konkretne rozwiązania prawne, które wyznaczają obszar problemowy zajęć z zakresu przedsiębiorczości. Oba wskazane wyżej aspekty normatywnego uwarunkowania edukacji w tematyce przedsiębiorczości stanowią przedmiot badawczy niniejszego opracowania. Oczywiście te dwie sfery nie są od siebie odseparowane, a wręcz przeciwnie - wzajemnie się przenikają i są komplementarne. Stanowi to argument dla ich łącznego zaprezentowania.

W kontekście prezentacji ogólnej podstawy prawnej nauczania przedsiębiorczości należy odwołać się do obecnie obowiązującej Ustawy z dnia 14 grudnia 2016 r. Prawo oświatowe (tekst jednolity: Dz.U. z 2020 r., poz. 910, z późn. zm.), która w sposób jednoznaczny deklaruje - w art. 1 pkt 18 - że: „System oświaty zapewnia w szczególności: [...] 18) kształtowanie u uczniów postaw przedsiębiorczości i kreatywności sprzyjających aktywnemu uczestnictwu w życiu gospodarczym, w tym poprzez stosowanie w procesie kształcenia innowacyjnych rozwiązań programowych, organizacyjnych lub metodycznych". $\mathrm{Na}$ marginesie warto odnotować, w ślad za piśmiennictwem, że deklarowane w art. 1 tej ustawy cele systemu oświaty mają charakter tylko przykładowy i można je uzupełniać, na co wskazuje użyte w przepisie sformułowanie „w szczególności” (Pyter, 2017: 6). Przytoczony wyżej przepis ustawy Prawo oświatowe nie wskazuje wprawdzie bezpośrednio na obowiązek nauczania przedsiębiorczości, tym niemniej - jak się wydaje - można na jego podstawie, w drodze wykładni, wyprowadzić wniosek o spoczywającej na władzach oświatowych powinności zapewnienia edukacji w tym zakresie. Pojawia się jednak pytanie o to, czy tego rodzaju - ustawowa - podstawa stanowi wystarczającą gwarancję kontynuacji nauczania przedsiębiorczości również w kolejnych latach. Znalezienie odpowiedzi na to pytanie stanowi pierwszy cel tego artykułu, przy czym jako hipotezę przyjęto, że nie jest to podstawa wystarczająca, w związku z czym należy postulować ujęcie kwestii nauczania przedsiębiorczości już na szczeblu konstytucyjnym. 
Jeżeli chodzi o drugi aspekt prawnych uwarunkowań nauczania przedsiębiorczości, tj. aspekt związany bezpośrednio z tematyką zajęć, to należy zwrócić tutaj uwagę na fakt, że ustawa Prawo oświatowe zobowiązała w art. 47 ust. 1 pkt 1 lit. a-h ministra właściwego do spraw oświaty i wychowania do określenia - w formie rozporządzenia - podstawy programowej wychowania przedszkolnego oraz kształcenia ogólnego dla: szkół podstawowych (włączając w to uczniów z umiarkowaną bądź znaczną niepełnosprawnością intelektualną), liceów ogólnokształcących, techników, branżowych szkół I stopnia, szkół specjalnych przysposabiających do pracy, branżowych szkół II stopnia, szkół policealnych, przy czym określając podstawy programowe, minister winien uwzględnić „,w szczególności zestawy celów kształcenia i treści nauczania, umiejętności uczniów, a także zadania wychowawczo-profilaktyczne szkoły, odpowiednio do poszczególnych etapów edukacyjnych i typów szkół”. Dla realizacji powyższego obowiązku wydano Rozporządzenie Ministra Edukacji Narodowej z dnia 14 lutego 2017 r. w sprawie podstawy programowej wychowania przedszkolnego oraz podstawy programowej kształcenia ogólnego dla szkoły podstawowej, $w$ tym dla uczniów $z$ niepelnosprawnościa intelektualna $w$ stopniu umiarkowanym lub znacznym, kształcenia ogólnego dla branżowej szkoły I stopnia, kształcenia ogólnego dla szkoły specjalnej przysposabiajacej do pracy oraz kształcenia ogólnego dla szkoły policealnej (Dz.U. z 2017 r., poz. 356, z późn. zm.) oraz Rozporządzenie Ministra Edukacji Narodowej z dnia 30 stycznia 2018 r. w sprawie podstawy programowej kształcenia ogólnego dla liceum ogólnokształcacego, technikum oraz branżowej szkoły II stopnia (Dz.U. z 2018 r., poz. $467, \mathrm{z}$ późn. zm.). Zgodnie z $\$ 3$ pierwszego ze wspomnianych rozporządzeń Ministra Edukacji Narodowej, weszło ono w życie w dniu 1 września 2017 r. Natomiast drugie z rzeczonych rozporządzeń Ministra Edukacji Narodowej (w skrócie: rozp. MEN z 30.01.2018 r.) obowiązuje od dnia 1 września 2018 r. ( $\$ 2$ rozp. MEN z 30.01.2018 r.). Dla większej przejrzystości wywodu oraz z uwagi na ograniczoną objętość niniejszego opracowania, oparciem dla dalszych analiz będą postanowienia zamieszczone w załączniku nr 1 (zatytułowanym Podstawa programowa kształcenia ogólnego dla czteroletniego liceum ogólnokształcącego i pięcioletniego technikum) do rozp. MEN z 30.01.2018 r. Jednocześnie należy zauważyć, że proces nauczania przedsiębiorczości nie może abstrahować od bieżących wydarzeń ekonomicznych, a wręcz przeciwnie - w procesie tym należy w możliwie najszerszym zakresie uwzględniać aktualny kontekst gospodarczy. Jest to szczególnie ważne dzisiaj, w okresie zawirowań ekonomicznych. Mianowicie występujące teraz u wielu przedsiębiorców trudności gospodarcze dobitnie pokazują, jak ważne jest uczulenie młodych ludzi - już na etapie szkoły - na fakt, że prowadzenie działalności gospodarczej daje nie tylko możliwość osiągania dużych zysków, ale również wiąże się ze sporym ryzykiem finansowym.

Mając powyższe na uwadze, drugim celem niniejszego opracowania jest wyeksponowanie - w ramach obowiązującej podstawy programowej - tych zagadnień związanych z ryzykiem finansowym, na które należałoby zwrócić szczególną uwagę podczas zajęć z uczniami. Jednocześnie postawiono hipotezę o częściowej nieadekwatności aktualnej podstawy programowej w stosunku do istniejących potrzeb w zakresie nauczania o ryzyku prowadzenia działalności gospodarczej, co w konsekwencji daje podstawę do sformułowania rekomendacji dotyczącej uzupełnienia podstawy programowej o wybrane rozwiązania prawne zawarte w Ustawie z dnia 28 lutego 2003 r. Prawo upadłościowe (tekst jednolity: Dz.U. z 2020 r., poz. 1228, z późn. zm.; dalej: P.u.). 
Przyjęta metoda badawcza. Prezentacja problematyki badawczej na tle aktualnego piśmiennictwa

Przyjęta w opracowaniu metoda badawcza polega na analizie i selekcji przepisów wybranych aktów prawnych, a następnie ich omówieniu w kontekście założonych celów opracowania. W szeregu przypadków konieczne było poddanie ich procedurze wykładni, która - jak wskazuje się w opracowaniach teoretycznoprawnych - ukierunkowana jest na określenie znaczenia oraz zakresu sformułowań ujętych w języku prawnym (Tobor, 1997: 193). Pojęcie języka prawnego służy do określenia języka, w którym sporządza się teksty prawne (Sarkowicz, 1998: 49). Dla lepszego zrozumienia praktycznych założeń tkwiących u podstaw powoływanych w opracowaniu przepisów zawartych w aktach normatywnych, wielokrotnie sięgano do aktualnego piśmiennictwa.

Charakteryzując omawianą w opracowaniu problematykę na tle dotychczasowych badań prezentowanych w literaturze przedmiotu, należy stwierdzić, że chociaż istnieje duża liczba pozycji literaturowych, a zwłaszcza komentarzy nawiązujących do poruszanych $\mathrm{w}$ artykule zagadnień, to jednak nie są to pozycje, których przedmiot badawczy pokrywałby się z celami i hipotezami niniejszego opracowania. Poglądy w nich wyrażone nawiązują jedynie pośrednio do kwestii poruszanych w tym artykule, co nie zmienia faktu, że istotnie dopełniają one prowadzone rozważania. Poniżej powołane zostaną te z pozycji literaturowych, które uznano za szczególnie ważne dla pogłębienia wybranych analiz, mogących zostać w niniejszym opracowaniu - z uwagi na ograniczenia redakcyjne - jedynie zasygnalizowanych. Dotyczy to ryzyka finansowego związanego z prowadzeniem działalności gospodarczej w formie spółek oraz procedury upadłościowej.

W pierwszej kolejności należy wskazać na liczne opracowania dotyczące prawnych aspektów funkcjonowania spółek. Istotne znaczenie mają tutaj badania prowadzone zwłaszcza przez W. Pyzioła i A. Kidybę. Ten pierwszy, analizując prawną konstrukcję spółki cywilnej, zwrócił uwagę m.in. na ryzyko ponoszone przez wspólnika takiej spółki, które odpowiednio wzrasta w przypadku zwiększania rozmiarów wykonywanej działalności (Pyzioł, 2016: 12). Z kolei Kidyba, w ramach pogłębionych rozważań na temat m.in. spółki partnerskiej, przeanalizował reguły rządzące odpowiedzialnością partnerów spółki za osoby podporządkowane (Kidyba, 2017: 432). Znaczenie badań wspomnianych autorów jest, z punktu widzenia obrotu gospodarczego, niezwykle ważne, bowiem ułatwia przedsiębiorcom szacowanie ryzyka przyszłej działalności gospodarczej.

Natomiast w odniesieniu do poruszanych w opracowaniu kwestii związanych z procedurą upadłościową należy wspomnieć o szerokich analizach prowadzonych w tym zakresie przez S. Gurgula (Gurgul, 2016) i P. Zimmermana (Zimmerman, 2016). Pogłębiony charakter tych opracowań pozwala istotnie rozszerzyć wiedzę z zakresu tej procedury, a w konsekwencji - w przypadku przedsiębiorców - zminimalizować koszty i problemy wynikające z niepowodzenia danego przedsięwzięcia gospodarczego.

\section{Nauczanie przedsiębiorczości a przepisy Konstytucji RP}

W przepisach Konstytucji Rzeczypospolitej Polskiej z dnia 2 kwietnia 1997 r. (Dz.U. z 1997 r. nr 78, poz. 483, z późn. zm.) jest mowa ogólnie o prawie do edukacji (zob. art. 70 Konstytucji RP). Brakuje w niej natomiast bezpośredniego odniesienia do kwestii nauczania przedsiębiorczości. Jak się wydaje, pominięcie tej sprawy jest konsekwencją przyjęcia 
założenia, że przepisy ustawy zasadniczej nie mogą być zbyt drobiazgowe i rozbudowane. Co do zasady, z takim założeniem należy się zgodzić. Z drugiej jednak strony konstytucyjne nawiązanie do kwestii nauczania przedsiębiorczości nie wymagałoby wprowadzania rozbudowanych rozwiązań prawnych. Wydaje się, że najbardziej odpowiednim miejscem dla uregulowania tej kwestii byłby jednak nie wspomniany wyżej art. 70 ustawy zasadniczej, ale - nawiązujący bezpośrednio do kwestii gospodarczych - art. 20 Konstytucji $R P$, który przewiduje, że: „Społeczna gospodarka rynkowa oparta na wolności działalności gospodarczej, własności prywatnej oraz solidarności, dialogu i współpracy partnerów społecznych stanowi podstawę ustroju gospodarczego Rzeczypospolitej Polskiej”. W kontekście sformułowanego wyżej postulatu de lege ferenda, dotyczącego uzupełnienia art. 20 Konstytucji $R P$, nasuwają się następujące pytania: jaka byłaby optymalna forma tej zmiany i jakie konsekwencje tego rodzaju zmiana niosłaby za sobą na przyszłość.

Gdy chodzi o kwestię formy, w jakiej należałoby zmodyfikować art. 20 Konstytucji $R P$, warto w tym zakresie przykładowo odwołać się do art. 65 ust. 5 Konstytucji $R P$, który stanowi: „Władze publiczne prowadzą politykę zmierzającą do pełnego, produktywnego zatrudnienia poprzez realizowanie programów zwalczania bezrobocia, w tym organizowanie i wspieranie poradnictwa i szkolenia zawodowego oraz robót publicznych i prac interwencyjnych”. Przepis ten, mówiąc najogólniej, kreuje dla władz publicznych zobowiązania do podejmowania odpowiednich działań, by możliwe było osiągnięcie zakładanego rezultatu. Nie ma przeszkód, aby analogiczne zobowiązanie, oczywiście z uwzględnieniem specyfiki problematyki, wkomponować do art. 20 Konstytucji RP. Zatem, traktując powyższą regulację z art. 65 ust. 5 Konstytucji $R P$ jako wzorzec, należałoby postulować dodanie do art. 20 Konstytucji RP ustępu 2 (dotychczasowa treść art. 20 Konstytucji RP oznaczona byłaby wówczas jako ustęp 1) o treści: „Zobowiązuje się władze państwowe i samorządowe do realizowania polityki ukierunkowanej na upowszechnianie wiedzy o podstawach funkcjonowania gospodarki, w tym społecznej gospodarki rynkowej, poprzez tworzenie odpowiednich programów nauczania, zwłaszcza z zakresu przedsiębiorczości”. Wprowadzenie wspomnianej wyżej regulacji do przepisów konstytucyjnych jest uzasadnione z uwagi na wynikające z tego dalekosiężne skutki.

W pierwszej kolejności należy pamiętać, że ujęcie w Konstytucji $R P$ kwestii nauczania przedsiębiorczości znacznie podniesie rangę i prestiż tego przedmiotu w szkołach. Ponadto, taka regulacja stanowiłaby swego rodzaju gwarancję stabilności w zakresie ujmowania przedsiębiorczości w programach edukacyjnych. Trzeba pamiętać, że takiej stabilności nie zapewnią same przepisy ustawowe, które mogą zostać stosunkowo łatwo zmienione. Warto przypomnieć, że zgodnie z art. 120 zdanie pierwsze Konstytucji $R P$, do uchwalenia ustawy przez Sejm potrzebna jest zwykła większość głosów (Konstytucja RP wymaga przy tym, aby obecna była przynajmniej połowa ustawowej liczby posłów), o ile Konstytucja RP nie przewiduje innej większości. Jak zatem można zauważyć, uchwalenie odpowiedniej ustawy uchylającej obowiązujące dziś przepisy jest względnie proste. Natomiast ewentualna zmiana przepisów konstytucyjnych jest dużo trudniejsza, co wynika chociażby z postanowień art. 235 ust. 4 Konstytucji $R P$ przewidującego, że ustawa zmieniająca Konstytucję $R P$ uchwalana jest przez „Sejm większością co najmniej 2/3 głosów w obecności co najmniej połowy ustawowej liczby posłów oraz Senat bezwzględną większością głosów w obecności co najmniej połowy ustawowej liczby senatorów”.

Oczywiście na kwestię możliwości zmiany Konstytucji RP można też spojrzeć z innej perspektywy. Otóż warto się zastanowić, czy proponowana wyżej modyfikacja brzmienia 
jej art. 20 byłaby w praktyce możliwa, biorąc pod uwagę przedstawione wyżej konstytucyjne obostrzenia związane z jej zmianą. Wydaje się jednak, że rzeczony postulat przekonstruowania rzeczonego przepisu jest na tyle niekontrowersyjny, iż mógłby znaleźć poparcie odpowiedniej większości parlamentarnej zgodnie z wymogami art. 235 ust. 4 Konstytucji RP. Tym niemniej nie można wykluczyć, że - przynajmniej w najbliższej perspektywie czasowej - osiągnięcie odpowiednio szerokiego porozumienia politycznego, warunkującego tę zmianę, nie będzie możliwe. Dlatego jako rozwiązanie doraźne, stanowiące niejako punkt wyjścia dla przyszłej zmiany Konstytucji $R P$, można rozważyć wpisanie do ustawy Prawo oświatowe przepisu, który wprost nakazywałby nauczanie przedsiębiorczości i stanowiłby tym samym wzmocnienie i rozwinięcie ogólnej intencji ustawodawcy zawartej w przywołanym na wstępie art. 1 pkt 18 ustawy Prawo oświatowe.

\section{Uwagi ogólne na temat zakresu nauczania przedsiębiorczości}

Jak wynika z treści wspomnianego załącznika nr 1 do rozp. MEN z 30.01.2018 r., podstawy przedsiębiorczości należą do tej kategorii przedmiotów, które w liceum ogólnokształcącym oraz technikum nauczane są jedynie w zakresie podstawowym. Jednocześnie, jak zostało to ujęte przez prawodawcę we wspomnianym załączniku (we fragmencie zawierającym ogólny opis przedmiotu podstawy przedsiębiorczości), przedmiot ten jest połączeniem ,wybranych celowo elementów wiedzy z zakresu ekonomii, zarządzania i finansów, wzbogaconej elementami geografii społeczno-ekonomicznej, politologii, socjologii, psychologii oraz prawa. [...] Zakres przedmiotu jest zgodny z powszechnie przyjmowaną definicją przedsiębiorczości jako kompetencji kluczowej. Uzasadnia to konieczność przyjęcia jego szeroko zakrojonej koncepcji, w której dzięki wyposażeniu uczniów w wiedzę ekonomiczną i finansową kształtuje się ich umiejętności elastycznego zachowania na rynku pracy i zarządzania oraz rozwija cechy przywódcze”.

Trzeba przyznać, że nakreślona wyżej materia przedmiotu podstawy przedsiębiorczości, łącząca zagadnienia z zakresu m.in. ekonomii, finansów i prawa, jest niezwykle bogata i zróżnicowana. Tezę tę potwierdza przegląd precyzyjnie wyszczególnionych zagadnień ujętych pod wspólnym tytułem Treści nauczania - wymagania szczegółowe (dalej: treści nauczania), zamieszczonych w części omawianego załącznika nr 1 do rozp. MEN z 30.01.2018 r. zatytułowanej Podstawy przedsiębiorczości. Zgodnie z koncepcją prawodawcy wyrażoną we wspomnianej wyżej części załącznika nr 1 do rozp. MEN z 30.01.2018 r., treści nauczania zostały podzielone na cztery rozbudowane działy, którymi są: Gospodarka rynkowa (dział I), Rynek finansowy (dział II), Rynek pracy (dział III) i Przedsiębiorstwo (dział IV), przy czym na każdy z tych działów musi zostać przeznaczone nie mniej niż: 8 godz. (dział I), 13 godz. (dział II), 12 godz. (dział III) i 19 godz. (dział IV). W sumie daje to 52 godz., a to z kolei wyczerpuje ok. $80 \%$ godz. pozostających w dyspozycji nauczyciela (pozostała liczba godzin, jak wskazuje prawodawca, może zostać przez nauczyciela przeznaczona na rozwinięcie określonych treści według jego własnego uznania).

Niezależnie od obszerności wskazanych treści, ich bliższa analiza, zwłaszcza z perspektywy aktualnej sytuacji gospodarczej, daje podstawę do sformułowania kilku spostrzeżeń. Trzeba bowiem mieć świadomość, że obecnie trwające trudności ekonomiczne dotknęły już wielu gałęzi gospodarki i spowodowały liczne bankructwa zarówno małych rodzinnych firm, jak i większych podmiotów gospodarczych. Niejednokrotnie taka upadłość 
wiąże się z ogromnym ludzkim nieszczęściem spowodowanym przejęciem majątku przez wierzycieli i koniecznością spłacania wysokich kredytów przez kolejne lata. Co więcej, należy oczekiwać, że skutki obecnej sytuacji będą odczuwalne - w mniejszym lub większym stopniu - w ciągu następnych lat.

Propozycje dotyczące ekspozycji wybranych zagadnień dotyczących ryzyka finansowego w ramach kształcenia z podstaw przedsiębiorczości (cykl koniunkturalny i spółka cywilna)

Mając na uwadze powyższe konstatacje, trudno oprzeć się wrażeniu, że zbyt mały nacisk został położony przez prawodawcę na kwestie związane z ryzykiem prowadzenia działalności gospodarczej. Oczywiście nie jest tak, że problematyka ta nie została w ogóle zaakcentowana w rzeczonych treściach nauczania. Można bowiem w nich odnaleźć pewne odniesienia do istotnych z tego punktu widzenia kategorii ekonomicznych i instytucji prawnych, tym niemniej wydaje się, że należałoby wzbogacić te treści o jeszcze inne zagadnienia. Postulaty dotyczące uzupełnienia treści nauczania w zakresie podstaw przedsiębiorczości o zagadnienia upadłościowe, regulowane przede wszystkim we wspomnianej już ustawie P.u., są przedstawione w końcowej części niniejszego artykułu. Natomiast w tej i następnej części opracowania wskazane zostaną propozycje dotyczące tych kwestii, na które należałoby szczególnie uczulić uczniów w ramach już istniejących możliwości programowych.

W pierwszej kolejności jako trafne i uzasadnione należy ocenić umieszczenie - w dziale I (Gospodarka rynkowa) treści nauczania - kwestii dotyczących faz cyklu koniunkturalnego. Jak zakłada prawodawca, w ramach tego zagadnienia uczeń przedstawia zmiany zachodzące w gospodarce „w kolejnych fazach cyklu koniunkturalnego, charakteryzuje narzędzia oddziaływania państwa na gospodarkę oraz dyskutuje na temat metod przeciwdziałania zjawiskom kryzysowym w gospodarce krajowej i światowej” (pkt 8 działu I treści nauczania). Podczas prezentacji tego tematu szczególnie istotne wydaje się spojrzenie na problematykę cyklu koniunkturalnego z pespektywy indywidualnego przedsiębiorcy. Uczniowie muszą mieć świadomość, że - jak wskazuje się w literaturze przedmiotu - faza kryzysu oznacza bankructwa, które dotykają podmiotów gospodarczych charakteryzujących się najwyższymi kosztami produkcji, a w fazie depresji czymś nieuniknionym są duże koszty społeczne, w tym bezrobocie (Tomczak, 2007: 458-459).

Kolejne zagadnienie, którego ujęcie w dziale IV (Przedsiębiorstwo) treści nauczania zasługuje na pełną aprobatę - patrząc zwłaszcza z pespektywy wspomnianych wyżej cyklicznych fluktuacji gospodarczych dotykających małych i średnich przedsiębiorców związane jest z charakterystyką podstawowych form organizacyjno-prawnych podmiotów gospodarczych, obejmujących indywidualną działalność gospodarczą, spółkę cywilną, spółki prawa handlowego, oraz przedsiębiorczości społecznej (włączając w to m.in. spółdzielnie pracy i spółdzielnie socjalne, stowarzyszenia i fundacje), jak również z doborem formy prawnej do przyszłych zamierzeń biznesowych, z uwzględnieniem odpowiedzialności prawnej i majątkowej właścicieli (pkt 6 działu IV treści nauczania).

Z dużą dozą prawdopodobieństwa można założyć, że wielu początkujących przedsiębiorców nie do końca ma świadomość, jak poważne i długofalowe konsekwencje finansowe może mieć dla ich majątków niepowodzenie rozpoczętej działalności gospodarczej. Problem ten ściśle wiąże się też z obowiązującymi w Polsce regulacjami upadłościowymi, 
przy czym - jak już wspomniano - uwagi na ten temat w kontekście proponowanych zmian w treściach nauczania podstaw przedsiębiorczości zamieszczono pod koniec niniejszego opracowania. Natomiast w niniejszej i następnej części artykułu wskazane zostaną wybrane rozwiązania wynikające z Ustawy z dnia 23 kwietnia 1964 r. Kodeks cywilny (tekst jednolity: Dz.U. z 2020 r., poz. 1740, z późn. zm.; dalej: K.c.) i Ustawy z dnia 15 września 2000 r. Kodeks spółek handlowych (tekst jednolity: Dz.U. z 2020 r., poz. 1526, z późn. zm.; dalej: K.s.h.), na które należałoby zwrócić szczególną uwagę w związku z omawianiem z uczniami kwestii odpowiedzialności majątkowej przedsiębiorców. Warto w tym kontekście podkreślić, że sam prawodawca - w załączniku nr 1 do rozp. MEN z 30.01.2018 r., w części zatytułowanej Warunki i sposób realizacji, zamieszczonej bezpośrednio po wyszczególnieniu treści nauczania z zakresu podstaw przedsiębiorczości - akcentuje, że: „W osiąganiu wielu efektów kształcenia istotną rolę odgrywa kształtowanie umiejętności czytania fragmentów aktów prawnych, takich jak: Kodeks pracy, Kodeks cywilny czy ustawa o swobodzie działalności gospodarczej. Oczywiście nie jest możliwe, aby uczniowie zapoznawali się na lekcji w całości z tymi aktami prawnymi. Konieczny jest więc staranny, celowy dobór niewielkich fragmentów, np. związanych z [...] ramami prawnymi funkcjonowania spółki cywilnej”. Na marginesie trzeba zauważyć, że przy okazji kolejnej nowelizacji rozp. MEN z 30.01.2018 r. należałoby zmienić powyższy zapis przez zastąpienie odniesienia do uchylonej już - na mocy postanowienia zawartego w art. 192 Ustawy $z$ dnia 6 marca 2018 r. Przepisy wprowadzajace ustawę Prawo przedsiębiorców oraz inne ustawy dotyczace działalności gospodarczej (Dz.U. z 2018 r., poz. 650) - Ustawy o swobodzie działalności gospodarczej, odwołaniem się do aktualnie obowiązującej Ustawy z dnia 6 marca 2018 r. Prawo przedsiębiorców (tekst jednolity: Dz.U. z 2021 r., poz. 162).

Analizę wybranych rozwiązań dotyczących spółki cywilnej należy rozpocząć od wskazania, że - zgodnie z art. $860 \$ 1$ ustawy K.c. - zawierając umowę takiej spółki wspólnicy nakładają na siebie obowiązek dążenia do realizacji wspólnego celu o charakterze gospodarczym, działając w określony sposób, a zwłaszcza wnosząc wkłady. Jednocześnie, zgodnie z art. 4 ust. 2 ustawy Prawo przedsiębiorców, wspólnicy takiej spółki mają status przedsiębiorców „,w zakresie wykonywanej przez nich działalności gospodarczej”.

W literaturze przedmiotu podkreśla się, że spółka cywilna jest szeroko stosowana w obrocie gospodarczym, przy czym zwłaszcza osoby fizyczne wykorzystują ją często do wspólnej realizacji przedsięwzięć gospodarczych (Radwański, Panowicz-Lipska, 2019: 326). Osoby te muszą jednak pamiętać, że ustawodawca nałożył na wspólników takiej spółki odpowiedzialność solidarną za jej zobowiązania (art. 864 K.c.). Przepis ten ma fundamentalne znaczenie z puntu widzenia ryzyka planowanej działalności gospodarczej. Należy uczulić uczniów na fakt, że - jak wskazuje się w doktrynie prawa - ze względu „na nieograniczoną, solidarną odpowiedzialność osobistą wspólników za wspólnie zaciągnięte zobowiązania (art. $864 \mathrm{KC}$ ), każdy wspólnik ryzykuje utratą nawet całego swojego osobistego majątku w razie, gdy spółka działa ze stratą. Ryzyko to jest tym większe, im większe są rozmiary wspólnie prowadzonej działalności” (Pyzioł, 2016: 12). Trzeba przy tym wskazać, czym w istocie jest solidarna odpowiedzialność. Pojęcie to zostało wyjaśnione w art. $366 \$ 1$ K.c., który stanowi: „Kilku dłużników może być zobowiązanych w ten sposób, że wierzyciel może żądać całości lub części świadczenia od wszystkich dłużników łącznie, od kilku z nich lub od każdego z osobna, a zaspokojenie wierzyciela przez któregokolwiek z dłużników zwalnia pozostałych (solidarność dłużników)”. Co więcej, dopóki nie nastąpi zupełne zaspokojenie wierzyciela, zobowiązanie wszystkich 
dłużników solidarnych pozostaje w mocy (art. $366 \$ 2$ K.c.). W piśmiennictwie akcentuje się, że w przypadku solidarności zobowiązania, wierzyciel ma prawo skierować do każdego podmiotu będącego wspólnikiem żądanie, aby ten spełnił świadczenie w pełnej wysokości, przy czym jeżeli któryś ze wspólników spełni świadczenie w całej wysokości, to pozostali będą już zwolnieni ze zobowiązania, a wspólnik, który zrealizował świadczenie, będzie mógł wystąpić, w drodze roszczenia regresowego, do pozostałych wspólników, aby ci zwrócili mu część świadczenia, które na nich przypada (Uliasz, 2019: 1749).

\section{Wskazówki w zakresie przybliżenia pozostałych rozwiązań dotyczących odpowiedzialności finansowej wspólników}

Poza odpowiedzialnością wspólników spółki cywilnej uzasadnione wydaje się wyeksponowanie w treściach nauczania kwestii dotyczących zasad odpowiedzialności wspólników funkcjonujących w ramach pozostałych kategorii spółek, uregulowanych w K.s.h. W niniejszej części artykułu zwrócono uwagę tylko na ściśle wyselekcjonowane uregulowania - odnoszące się do ryzyka związanego z działalnością gospodarczą w formie spółek ujętych w K.s.h., a obciążającego wspólników - które są najważniejsze dla zrozumienia istoty tego ryzyka. Z tego punktu widzenia podstawowe znaczenie mają zamieszczone w K.s.h. rozwiązania dotyczące spółek osobowych, którą to kategorię tworzą, w myśl art. $4 \$ 1$ pkt 1 K.s.h., spółka jawna, spółka partnerska, spółka komandytowa i spółka komandytowo-akcyjna.

W pierwszej kolejności należy wskazać, że - jak stanowi art. $22 \$ 2$ K.s.h. - w przypadku spółki jawnej na każdym wspólniku spoczywa odpowiedzialność za jej zobowiązania, przy czym odpowiedzialność ta - obejmująca cały jego majątek - jest solidarna z innymi wspólnikami i samą spółką, jednak z uwzględnieniem postanowień art. 31 K.s.h. O ile kwestia solidarności została już wyżej wytłumaczona, o tyle należy objaśnić w tym miejscu znaczenie odwołania do przepisu art. $31 \mathrm{~K} . s . h$. Mianowicie przepis ten definiuje w uregulowanych w K.s.h. $\$ 1$ pojęcie subsydiarnej odpowiedzialności wspólnika, która polega na tym, że wierzyciel spółki jest uprawniony do prowadzenia egzekucji z majątku należącego do wspólnika w sytuacji, gdy egzekucja skierowana do majątku spółki okazała się bezskuteczna. W istocie zatem, zgodnie z poglądem doktryny, to spółka jawna, będąca odrębnym od wspólników podmiotem prawa i dysponująca własnym majątkiem, będzie ponosić pierwszorzędną odpowiedzialność, a odpowiedzialność subsydiarna obciążająca wspólników oznacza jej wtórny charakter (Borowy, 2017: 173-174).

Odrębnie przedstawia się kwestia odpowiedzialności wspólników w spółce partnerskiej, bowiem w takiej spółce ustawodawca zwalnia partnera od „odpowiedzialności za zobowiązania spółki powstałe w związku z wykonywaniem przez pozostałych partnerów wolnego zawodu w spółce, jak również za zobowiązania spółki będące następstwem działań lub zaniechań osób zatrudnionych przez spółkę na podstawie umowy o pracę lub innego stosunku prawnego, które podlegały kierownictwu innego partnera przy świadczeniu usług związanych z przedmiotem działalności spółki” (art. $95 \$ 1$ K.s.h.). Trzeba wyjaśnić, odwołując się do poglądu doktryny, że wspomniane w przytoczonym wyżej przepisie osoby podlegające kierownictwu to np. asystenci czy pomoc techniczna, przy czym o odpowiedzialności partnera za te osoby (podporządkowane) można mówić jedynie wtedy, gdy wykonują one usługi związane $\mathrm{z}$ zakresem działalności danej spółki, a jeżeli brak jest takiego związku, to zobowiązania, które te osoby zaciągnęły, będą obciążały zarówno spółkę, jak i wszystkich partnerów niezależnie od reguł podporządkowania (Kidyba, 2017: 432). 
Podążając dalej zgodnie z systematyką ustawy K.s.h., należy wskazać na zasady odpowiedzialności wspólników spółki komandytowej, wynikające z samej definicji spółki, do której istoty należy - zgodnie z art. 102 K.s.h. - to, że jest ona spółką osobową sprofilowaną na „prowadzenie przedsiębiorstwa pod własną firmą, w której wobec wierzycieli za zobowiązania spółki co najmniej jeden wspólnik odpowiada bez ograniczenia (komplementariusz), a odpowiedzialność co najmniej jednego wspólnika (komandytariusza) jest ograniczona”. Wskazuje się w literaturze przedmiotu (przez odwołanie się do art. $103 \$ 1$ K.s.h. i odpowiednich przepisów dotyczących spółki jawnej), że komplementariusz takiej spółki będzie odpowiadał w stosunku do osób trzecich w taki sam sposób, jak ma to miejsce w wypadku spółki jawnej (Szumański, 2016: 146).

Szczególnie interesująca, z punktu widzenia ryzyka gospodarczego, jest pozycja komandytariusza, który - inaczej niż komplementariusz - odpowiada w sposób ograniczony. Pojawia się zatem pytanie, na czym polega ta ograniczoność odpowiedzialności. Stanowi o tym art. 111 K.s.h., który redukuje odpowiedzialność komandytariusza za zobowiązania omawianej spółki, w stosunku do jej wierzycieli, do kwoty sumy komandytowej. O sumie komandytowej wspomina z kolei art. 105 pkt 5 K.s.h., z którego wynika, że jest ona elementem umowy spółki komandytowej, ujmującym w sposób kwotowy zakres odpowiedzialności - przyporządkowany każdemu z komandytariuszy - wobec wierzycieli. Należy jednak wyeksponować fakt, że - jak zaznacza się w literaturze przedmiotu - pomimo iż odpowiedzialność komandytariusza może być realizowana do kwoty sumy komandytowej, to jednak będzie on odpowiadał całością swojego majątku i to nie tylko tym, który aktualnie posiada, ale także przyszłym (Szczurowski, 2017: 399).

Ostatnią spółką osobową, której działalność jest uregulowana w K.s.h., jest spółka komandytowo-akcyjna. Jak stanowi art. 125 K.s.h., spółka ta, będąc spółką osobową, jest nastawiona na „prowadzenie przedsiębiorstwa pod własną firmą, w której wobec wierzycieli za zobowiązania spółki co najmniej jeden wspólnik odpowiada bez ograniczenia (komplementariusz), a co najmniej jeden wspólnik jest akcjonariuszem". W przypadku akcjonariusza ustawodawca zwolnił go z ponoszenia odpowiedzialności za zobowiązania rzeczonej spółki (art. 135 K.s.h.).

\section{Rekomendacje w odniesieniu do uzupełnienia treści nauczania podstaw przedsiębiorczości o wybrane kwestie związane z przepisami upadłościowymi}

Uwzględniając obiektywnie rosnące znaczenie regulacji zawartych w ustawie P.u., zwłaszcza w dobie pogorszenia sytuacji ekonomicznej, w pełni uzasadniony jest postulat wyodrębnienia $\mathrm{w}$ treściach nauczania $\mathrm{z}$ zakresu podstaw przedsiębiorczości osobnego tematu dotyczącego przepisów upadłościowych, przy czym wydaje się, że optymalnym do tego miejscem byłby dział IV (Przedsiębiorstwo) w ramach treści nauczania. Mając oczywiście na uwadze bardzo ograniczone ramy czasowe, jakie można przeznaczyć na kształcenie uczniów w tym dość złożonym obszarze tematycznym, poniżej przedstawione zostaną propozycje jedynie najistotniejszych zagadnień, które należałoby poruszyć w trakcie zajęć.

Przede wszystkim trzeba zaznaczyć, że przepisy omawianej ustawy znajdą zastosowanie do przedsiębiorców określonych w ustawie K.c., o ile ustawa P.u. nie postanawia inaczej (art. 5 ust. 1 P.u.). Co więcej, przepisami ustawy P.u. objęci są również m.in. wspólnicy osobowych spółek handlowych, odpowiadający za zobowiązania takich spółek bez ograniczenia całością swojego majątku, a także wspólnicy spółek partnerskich (art. 5 ust. 2 pkt 2 i 3 P.u.). 
Osoba fizyczna, która miała status przedsiębiorcy, musi się liczyć z tym, że również po zakończeniu prowadzenia działalności gospodarczej wierzyciel zachowuje prawo do złożenia wniosku o ogłoszenie jej upadłości, o ile nie upłynął jeszcze rok liczony od dnia, w którym dokonano wykreślenia $\mathrm{z}$ odpowiedniego rejestru (art. 8 ust. 1 zdanie pierwsze P.u.). Regulacja ta będzie miała odpowiednie zastosowanie wobec osób, które straciły status wspólnika osobowej spółki handlowej (art. 8 ust. 2 P.u.). Ustawa jednocześnie wyjaśnia, że upadły to „ten, wobec kogo wydano postanowienie o ogłoszeniu upadłości” (art. 185 ust. 1 P.u.).

Ogłoszenie upadłości następuje „w stosunku do dłużnika, który stał się niewypłacalny" (art. 10 P.u.). Samo pojęcie niewypłacalności ma swój specyficzny, prawny sens, określony w art. 11 P.u., co też należałoby zaakcentować w trakcie zajęć z uczniami. Przede wszystkim, niewypłacalność dłużnika następuje wówczas, gdy nie ma on już zdolności do realizacji swoich zobowiązań pieniężnych, które są wymagalne (art. 11 ust. 1 P.u.). Niezwykle istotne jest wprowadzone przez ustawodawcę domniemanie, wedle którego „dłużnik utracił zdolność do wykonywania swoich wymagalnych zobowiązań pieniężnych, jeżeli opóźnienie w wykonaniu zobowiązań pieniężnych przekracza trzy miesiące" (art. 11 ust. 1a P.u.).

Należy mieć również świadomość, że z dniem, w którym nastąpi ogłoszenie upadłości, majątek upadłego przeistacza się w masę upadłościową, służącą zaspokojeniu jego wierzycieli (art. 61 P.u.). Z tym też dniem upadły zostaje pozbawiony prawa zarządu oraz nie może już korzystać z mienia objętego masą upadłości i rozporządzać nim (art. 75 ust. 1 P.u.). Natomiast wspomniana masa upadłościowa obejmuje majątek posiadany przez upadłego na dzień ogłoszenia upadłości, jak też nabyty przez niego w trakcie postępowania upadłościowego, chociaż z pewnymi wyjątkami wyszczególnionymi w art. 63-67a P.u. (art. 62 P.u.). Przykładowo, masą upadłości nie obejmuje się wynagrodzenia za pracę uzyskiwanego przez upadłego, ale jedynie w części, która nie podlega zajęciu (art. 63 ust. 1 pkt 2 P.u.). Oczywiście wyłącza się również z masy upadłości wszelkie składniki mienia, które nie są częścią majątku upadłego (art. 70 P.u.). Jak wskazuje się w piśmiennictwie, dany składnik majątkowy wyłącza się z masy upadłości zazwyczaj ze względu na fakt, że jest on własnością innej osoby (Gurgul, 2016: 157). Warto jednak pamiętać o istnieniu ustawowego domniemania, że rzeczy, które upadły posiada na dzień ogłoszenia upadłości są częścią jego majątku (art. 69 ust. 3 P.u.).

Na koniec warto też wskazać przykłady innych, szczegółowych rozwiązań, które istotnie modyfikują sytuację prawną upadłego. W szczególności, masę upadłości wzbogaca spadek w sytuacji, gdy upadły zostanie powołany do spadku, który został otwarty po dniu, w którym ogłoszono upadłość (art. 119 ust. 1 zdanie pierwsze P.u.). Jest to zasada, od której przewidziano jednak wyjątki (zob. zwłaszcza art. $121 \$ 2$ P.u.). Sankcją nieważności dotknięta będzie umowa, mocą której upadły zbywa całość bądź część spadku albo całość bądź część udziału spadkowego, o ile jej zawarcie nastąpiło później niż ogłoszenie upadłości (art. 120 zdanie pierwsze P.u.). Upadły musi się również liczyć z tym, że jego zobowiązania pieniężne - mimo że termin płatności danego świadczenia wciąż nie nadszedł - staną się wymagalne i to już z dniem, w którym nastąpi ogłoszenie upadłości (art. 91 ust. 1 P.u.). Na przykład, jak zauważa się w literaturze, gdy umowa nie zawiera terminu, w jakim należy spełnić świadczenie bądź jest on uwarunkowany wypowiedzeniem jednej ze stron umowy, to w takiej sytuacji zastrzeżenie nie będzie już miało mocy prawnej, a wymagalność zobowiązania zaistnieje z dniem, w którym ogłoszono upadłość (Zimmerman, 2016: 194). 


\section{Podsumowanie}

Przedstawione $\mathrm{w}$ niniejszym opracowaniu normatywne uwarunkowania w zakresie nauczania przedsiębiorczości, pozwalają sformułować pewne wnioski i rekomendacje, których uwzględnienie powinno spowodować, że edukacja w tym obszarze tematycznym będzie nie tylko silniej ugruntowana w polskim systemie oświaty, ale również wyczuli młodych ludzi na ryzyko związane z prowadzeniem działalności gospodarczej w niestabilnych warunkach ekonomicznych.

Na postawione na wstępie pytanie dotyczące tego, czy ustawowa podstawa nauczania przedsiębiorczości zapewnia w wystarczającym stopniu, że będzie ono kontynuowane w przyszłości, należy udzielić negatywnej odpowiedzi, co z kolei potwierdza sformułowaną w tym zakresie hipotezę. Jako uzasadnienie wskazano stosunkową łatwość uchwalania w Polsce nowych ustaw. Rozwiązaniem tej niekorzystnej sytuacji mogłoby być ujęcie tej kwestii w Konstytucji RP, co nie tylko gwarantowałoby trwałość rozwiązań prawnych, ale również podniosłoby znaczenie nauczania przedsiębiorczości w szkolnictwie. W konsekwencji sformułowano pod adresem ustawodawcy wniosek de lege ferenda dotyczący sposobu sformułowania odpowiedniego przepisu w ustawie zasadniczej.

Kolejna kwestia, która została poddana analizie w niniejszym artykule, dotyczy zagadnień nauczanych w trakcie zajęć z przedsiębiorczości na podstawie podstawy programowej ujętej w załączniku nr 1 do rozp. MEN z 30.01.2018 r. Analizę tę przeprowadzono z perspektywy ryzyka finansowego, będącego nieodłącznym elementem działalności biznesowej. Istniejące realia gospodarcze silnie wpływają na sytuację ekonomiczną przedsiębiorców, z których część jest zmuszonych zamknąć swoją działalność biznesową, przy czym niejednokrotnie stanowi to dopiero początek ich kłopotów finansowych związanych chociażby z koniecznością zwrotu kredytów zaciągniętych w ramach założonych przez nich spółek. Uwzględniając to tło gospodarcze, a zwłaszcza konieczność uświadomienia uczniom, że prowadzenie działalności gospodarczej wiąże się z ponoszeniem znacznego ryzyka, jako drugi cel niniejszego opracowania postawiono sobie wyeksponowanie tych zagadnień, których nauczanie pozwoli im - jako przyszłym przedsiębiorcom - bezpiecznie i odpowiedzialnie funkcjonować w okresach różnego rodzaju fluktuacji ekonomicznych. Cel ten zrealizowano, wskazując przede wszystkim na odpowiednie regulacje z zakresu prawa spółek. Jednocześnie przegląd obowiązujących zagadnień z podstawy programowej potwierdził hipotezę, że nie jest ona w pełni dostosowana do nauczania o ryzyku prowadzenia działalności gospodarczej, zwłaszcza gdy chodzi o problematykę związaną z przepisami upadłościowymi. Dlatego też sformułowano odpowiednią rekomendację dotyczącą ujęcia - jako odrębnego tematu w ramach treści nauczania o podstawach przedsiębiorczości - kwestii związanej z upadłością. Jednocześnie zaproponowano, na podstawie przepisów ustawy P.u., zbiór pewnych zagadnień, których omówienie na zajęciach przybliżyłoby uczniom tę, jak się wydaje niezbyt dobrze znaną, tematykę.

Prowadzone w niniejszym artykule rozważania opierały się na analizie przepisów prawa. Co jednak oczywiste, prawnicza metoda nie pozwala na wielopłaszczyznowe badanie zjawisk, bowiem odwołuje się ona przede wszystkim do samej treści norm prawnych. Natomiast wydaje się, że zjawiskiem, które należałoby zbadać nie tylko od strony prawnej, ale i od strony empirycznej, jest właśnie poruszona w tym artykule kwestia ryzyka finansowego prowadzenia działalności gospodarczej. Istotne byłoby zwłaszcza uzyskanie od uczniów odpowiedzi na pytania o to, w jakim stopniu są oni świadomi tego ryzyka i który 
aspekt wykonywania działalności gospodarczej budzi ich największe obawy. Ustalenia te pozwoliłyby na wprowadzenie kolejnych udoskonaleń do procesu nauczania przedsiębiorczości.

Akty prawne i literatura

Legal acts and references

Konstytucja Rzeczypospolitej Polskiej z dnia 2 kwietnia 1997 r. (Dz.U. z 1997 r. nr 78, poz. 483, z późn. $\mathrm{zm}$.).

Ustawa z dnia 23 kwietnia 1964 r. Kodeks cywilny (tekst jednolity: Dz.U. z 2020 r., poz. 1740, z późn. $\mathrm{zm}$.).

Ustawa z dnia 15 września 2000 r. Kodeks spółek handlowych (tekst jednolity: Dz.U. z 2020 r., poz. 1526, $\mathrm{z}$ późn. $z \mathrm{zm}$.).

Ustawa z dnia 28 lutego 2003 r. Prawo upadłościowe (tekst jednolity: Dz.U. z 2020 r., poz. 1228, z późn. $\mathrm{zm}$.).

Ustawa z dnia 14 grudnia 2016 r. Prawo oświatowe (tekst jednolity: Dz.U. z 2020 r., poz. 910, z późn. $\mathrm{zm}$.).

Ustawa z dnia 6 marca 2018 r. Prawo przedsiębiorców (tekst jednolity: Dz.U. z 2021 r., poz. 162).

Ustawa $z$ dnia 6 marca 2018 r. Przepisy wprowadzające ustawę - Prawo przedsiębiorców oraz inne ustawy dotyczace działalności gospodarczej (Dz.U. z 2018 r., poz. 650).

Rozporzadzenie Ministra Edukacji Narodowej z dnia 14 lutego 2017 r.w sprawie podstawy programowej wychowania przedszkolnego oraz podstawy programowej kształcenia ogólnego dla szkoly podstawowej, w tym dla uczniów z niepetnosprawnościq intelektualna $w$ stopniu umiarkowanym lub znacznym, kształcenia ogólnego dla branżowej szkoły I stopnia, kształcenia ogólnego dla szkoły specjalnej przysposabiajacej do pracy oraz kształcenia ogólnego dla szkoły policealnej (Dz.U. z 2017 r., poz. 356, z późn. zm.).

Rozporzadzenie Ministra Edukacji Narodowej z dnia 30 stycznia 2018 r.w sprawie podstawy programowej kształcenia ogólnego dla liceum ogólnokształcacego, technikum oraz branżowej szkoły II stopnia (Dz.U. z 2018 r., poz. 467, z późn. zm.).

Borowy, B. (2017). W: Z. Jara (red.), Kodeks spótek handlowych. Komentarz. Warszawa: Wydawnictwo C.H.Beck.

Gurgul, S. (2016). Prawo upadłościowe. Prawo restrukturyzacyjna. Komentarz. Warszawa: Wydawnictwo C.H.Beck.

Kidyba, A. (2017). Kodeks spółek handlowych. Tom I. Komentarz do art. 1-300. Warszawa: Wolters Kluwer.

Pyter, M. (2017). W: M. Pyter, A. Balicki, Prawo oświatowe. Komentarz. Warszawa: Wydawnictwo C.H.Beck.

Pyzioł, W. (2016). Rozdział I. Spółka cywilna. W: W. Pyzioł, A. Szumański, I. Weiss, Prawo spółek. Warszawa: Wydawnictwo C.H.Beck, 1-35.

Radwański, Z., Panowicz-Lipska, J. (2019). Zobowiązania - część szczegółowa. Warszawa: Wydawnictwo C.H.Beck.

Sarkowicz, R. (1998). II. Problematyka językowa w prawoznawstwie. W: R. Sarkowicz, J. Stelmach, Teoria prawa. Kraków: Wydawnictwo Uniwersytetu Jagiellońskiego, 39-58.

Szczurowski, T. (2017). W: Z. Jara (red.), Kodeks spótek handlowych. Komentarz. Warszawa: Wydawnictwo C.H.Beck.

Szumański, A. (2016). Rozdział IV. Spółka komandytowa. W: W. Pyzioł, A. Szumański, I. Weiss, Prawo spółek. Warszawa: Wydawnictwo C.H.Beck, 100-147.

Tobor, Z. (1997). Rozdział 8. Wykładnia prawa. W: J. Nowacki, Z. Tobor, Wstęp do prawoznawstwa. Katowice: Naukowa Oficyna Wydawnicza, 191-212. 
Tomczak, A. (2007). Rozdział 21. Koniunktura gospodarcza. W: S. Marciniak (red. naukowy), Makroi mikroekonomia. Podstawowe problemy. Warszawa: Wydawnictwo Naukowe PWN, 450-475.

Uliasz, R. (2019). W: M. Załucki (red.), Kodeks cywilny. Komentarz. Warszawa: C.H. Beck.

Zimmerman, P. (2016). Prawo upadłościowe. Prawo restrukturyzacyjne. Komentarz. Warszawa: Wydawnictwo C.H.Beck.

Paweł Marek Woroniecki, dr nauk prawnych, Uniwersytet Jagielloński w Krakowie, Wydział Prawa i Administracji, Katedra Publicznego Prawa Gospodarczego i Polityki Gospodarczej. Jego zainteresowania badawcze dotyczą prawnych aspektów funkcjonowania finansów państwowych i samorządowych, normatywnego statusu przedsiębiorców, warunków i form wykonywania działalności gospodarczej oraz prawnych reguł wyznaczających strukturę i kompetencje organów administracji publicznej, zwłaszcza w sferze gospodarczej.

Paweł Marek Woroniecki, doctor of legal sciences, the Jagiellonian University in Kraków, the Faculty of Law and Administration, the Chair of Public Economic Law and Economic Policy. His research interests refer to legal aspects of functioning of government and local government finances, normative status of entrepreneurs, conditions and forms of conducting economic activity, as well as legal rules assigning a structure and competences of public administration organs, especially in economic sphere.

ORCID: https://orcid.org/0000-0002-0352-1042

\section{Adres/Address:}

Uniwersytet Jagielloński w Krakowie

Wydział Prawa i Administracji

Katedra Publicznego Prawa Gospodarczego i Polityki Gospodarczej

ul. Bracka 12

31-005 Kraków, Poland

e-mail: pawel.woroniecki@uj.edu.pl 